\title{
Hidden Economy in the Hungarian Food Production ${ }^{1}$
}

\author{
Gyöngyi KÜRTHY, Budapest*
}

with 6 figures in the text

Content

Summary

161

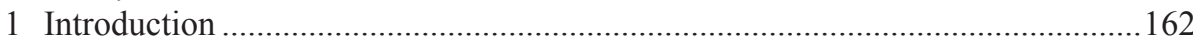

2 Types of and reasons for tax avoidance in Hungary............................................... 164

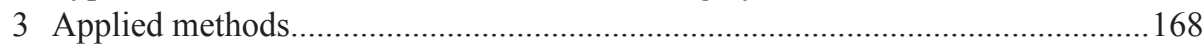

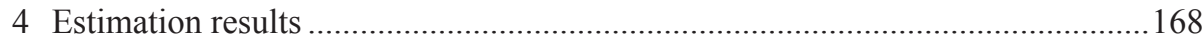

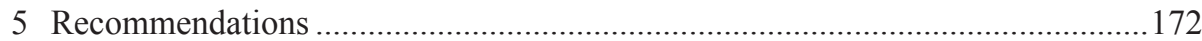

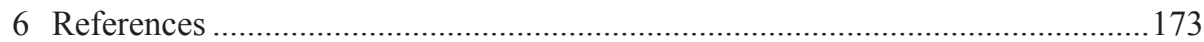

\section{Summary}

The paper addresses the shadow economy in the food economy in Hungary, which has increased significantly in the recent years. Different approaches and methods will be presented in the paper, with which the illegal activities were identified and their size was measured.

The size and weight of the illegal economy in this sector were calculated primarily with bottom-up methods, comparing the different available statistical databases. In foreign trade, where value-added tax (VAT) fraud particularly has increased, the size

$1 \quad$ This paper is based on a research carried out by the Department of Food Chain Analysis and the Department of Agricultural Policy of the Research Institute for Agricultural Economics, Hungary, in 2014 by the leadership of the author. Contributors to this research were: Katalin Aliczki, Gyula Dudas, Ildiko Ehretne Berczi, Beata Felkai, Robert Garay, Daniel Gyore, Laszlo Nagy, Katalin Szekelyhidi, Szilvia Nemeth, Edina Varga, Hartmut Wagner.

* Gyöngyi Kürthy, PhD., Senior researcher, Head of Department Food Chain Analysis, Research Institute for Agricultural Economics, Zsil u. 3-5. 1093, Budapest, Hungary; email: jankune.kurthy.gyongyi@aki.gov.hu 
of the tax gap and the main relations were determined with the aid of import and export differences and asymmetry indicators. To estimate the overall share of the shadow economy in the food industry, the results of the tax audits of the years 2007-2012 of the National Tax Office were used. Based on these data, the average tax loss per audit was determined, multiplied by the number of registered business entities. Due to the fact that according to the literature this method overestimates the real tax fraud as the audits usually concentrate on the risky firms, the result was reduced by $45 \%$. The authorities were also asked in interviews what type of tax frauds they experience, which sectors are most affected and what experiences they have gathered so far in the fight against the shadow economy. In the final part of the analysis direct interviews were used. For this purpose, the most-affected sectors (cereals, oil plants, sugar, fruit and vegetable sector, wineries and meat processing) were selected and 57 targeted experts were interviewed.

According to our results the overall tax gap is 23.3 to 33.3 billion Euros in the total economy, which would mean 24.1-34.3\% of the Gross Domestic Product (GDP). Assuming and verifying that the share of agriculture in the hidden economy is higher than in the economy as a whole, we estimate that the size of the shadow economy in food production to be 2.2 to 3.2 billion Euros.

\section{Introduction}

The shadow economy is a phenomenon that affects all countries of the world, but shows strong deviations within the individual national economies (Fig. 1).

In Hungary, especially in the recent years, the shadow economy in the area of the food economy has become more and more problematic and gained an important role in the public discussion. It causes a serious deficit in the Government's central budget but also distorts the rules of market economy as it gives an undeserved advantage to those stakeholders, which would not be competitive in a normal market environment. In this way, the high proportion of shadow economy supports a wrong market structure, helps ensure the survival of uncompetitive companies and thus worsens the overall competitiveness of the Hungarian food economy.

In the research carried out in 2014, we tried to study this phenomenon objectively, basing our research on available data as well as verifiable facts and making calculations and estimations on the proportion of illegal activity concerning the food economy using scientific methods recommended by international literature.

The hidden economy is defined in several ways by different authors. According to FLEMING et al. (2000) the shadow economy is the economic activity and the income gained by this activity, which avoids governmental control and tax payment. SCHNEIDER \& ENTE (2003) interpret the national economy as a dual organisation with an official 
Figure 1: Share of shadow economy in the European countries, 2013 (expressed in the share of GDP, \%)

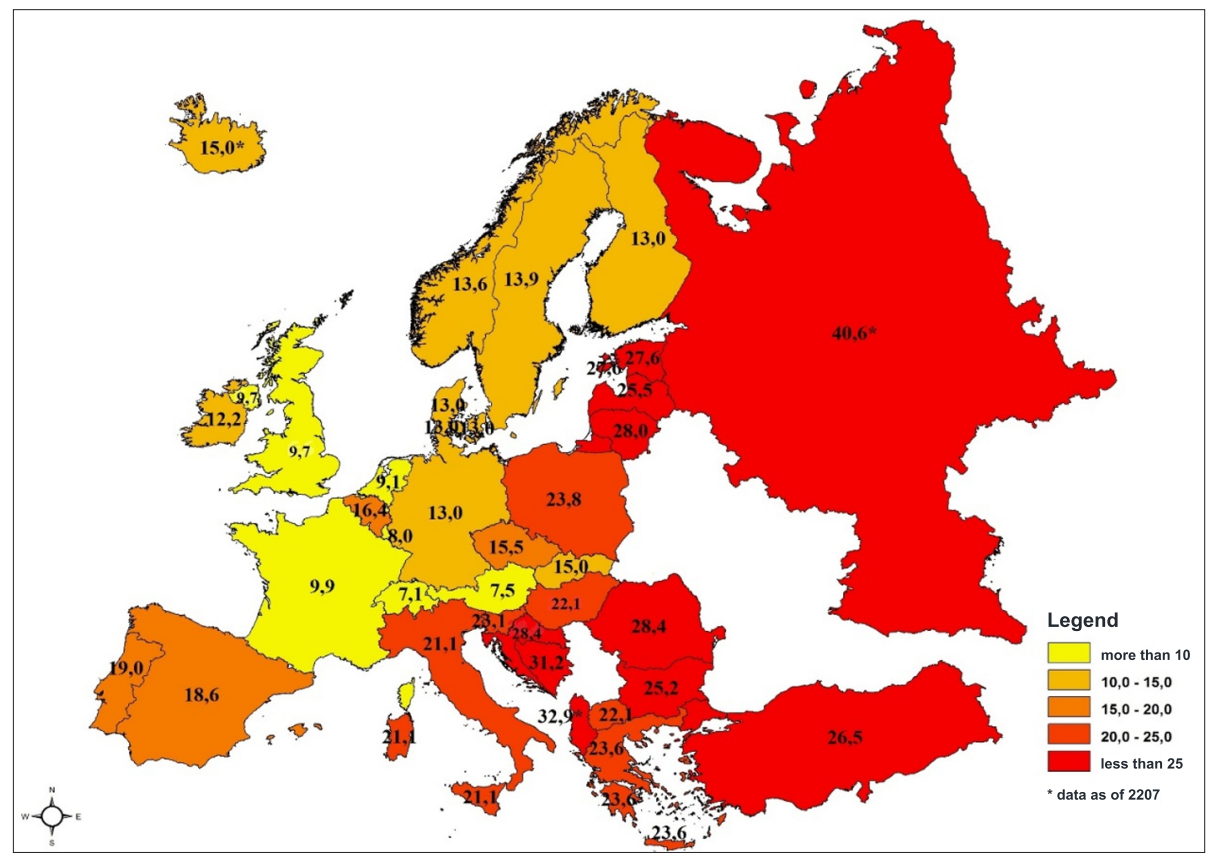

Source: Estimations by Schneider et al. (2010), Schneider (2013) and Schneider \& Buehn (2013)

(First Economy) and an unofficial (Second Economy, Informal Economic Activities) sector. Within the formal sector they separate the public and private sectors, whereby there might be "unregistered" elements (e.g., cover-up of revenue, illegal employment) in the formal sector and private sector, too. NAGY (2010) has shown that the Hungarian society accepts illegal economic activities more easily: $94 \%$ of the Hungarians do not ask for an invoice at grocery shops. $68 \%$ accept it if consumers buy for themselves but ask for an invoice for somebody else. According to 53\% it is normal if somebody receives a part of his/her salary 'in hand', i.e. without taxes and social insurance contribution fees.

Some authors found some advantages in the shadow economy. Tax fraud can be a tool against the unjustified, uncontrolled income greed of the Government (BRENNAN \& BUCHANAN 1993). If the use of the public financial resources are inefficient, the level of public services is low and the public financial resources disappear, tax fraud can increase social welfare (Cullis \& Jones 2003). Nevertheless, we assumed that the overall effects of the shadow economy is harmful, this is why it is important to explore its operation and develop methods to prevent it. 
Activities in the shadow economy can be sorted into several groups. According to the degree of the crime we can distinguish:

- 'Tax optimisation' meaning tax reduction using the legal possibilities;

- 'Tax evasion/tax avoidance' meaning hiding/reducing the incomes, increasing the costs;

- 'Tax fraud' which means false documentation, not paying taxes or unauthorised tax refund.

\section{Types of and reasons for tax avoidance in Hungary}

Based on KReKo \& KISS (2008) we explored the typical tax avoidance and tax fraud methods in Hungary:

- Value-added tax (VAT) fraud:

- Hidden consumption. Both the consumers and the companies gain, if the company does not give an invoice. The consumers can save a part of the VAT in the price, the company gains the other part of the VAT and some additional taxes.

- Hidden import of products

- Non-authorised tax refund

- Hiding taxes and social contribution fees on wages:

○ Hidden wages: 'black' or 'grey' employment, totally unregistered employment or registered employment, where a part of the wage is hidden.

- Wages accounted for as capital income: typical in self-employment. It is up to the owner of the firm to decide how much is paid for himself, and he is interested in paying minimal wage as social contribution fee (which is a lot higher than personal income tax). The contribution fee paid after capital income is lot lower and maximised.(The contribution fee is $18,5+27 \%$ after wages without maximum amount, while it is $27 \%$ after capital income and maximum cc. 1450 Euros per year per person).

- Hiding taxes on capital income:

- Small and medium enterprises (SMEs) usually reduce their taxes by invoices of personal consumption.

- Hidden company incomes

○ Multinational companies: tax optimisation

One of the main reasons behind the high share of the shadow economy in Hungary is the tax and social contribution system, which firstly stimulates tax avoidance through high tax rates and social contribution fees, and secondly allows for the hiding of income. 
In Hungary, the salary dues (taxes on wages and social contribution fee) are very high; in 2009 it was $53.1 \%$ and $49.4 \%$ in 2013 after a reduction of the tax on wages to $16 \%$. With this rate, Hungary was fourth highest amongst OECD countries in 2013 and second (!) in 2009. Employees and employers are both interested in hiding the official wages. The employer saves a part of the labour cost and it is also beneficial for the employees if a part of the saved cost is passed onto them. They do not lose anything as the amount and/or the quality of the public social services (healthcare, social payment for sick people, pension, etc.) has no direct connection with the amount of the contribution.

It is especially easy to avoid the payment in case of self-employed people. Owners of companies must pay social contribution fees only after minimal wage, other parts of their income they can receive as profit, which is from a social contribution fee. It is no wonder that there were 1.8 million firms in Hungary in 2013, which is an extremely high number compared to the number of active population, which was around four million people in the same year. According to the data of the National Tax Office the average wages for self-employed persons were only $24-27 \%$ that of the average of employees between 2005 and 2011.

Furthermore, there is a special tax relief system in agriculture, where smallscale farmers enjoy very favourable tax exempt. It is open to small farms but bigger agricultural companies also use this relief by hiding their income over the limit of the tax exempt or founding more agricultural farms and thus multiplying the relief.

The rate of VAT in Hungary is the highest among the OECD countries at 27\%. Both the end consumers and the companies are interested in hiding the transactions, meaning a price reduction for the consumers and less official income for the firms.

The high rate of VAT stimulates the professional, international tax fraud, which is not only a Hungarian problem. The main reason is that within the EU the products can move freely, there are no tariffs, no border controls, authorities can investigate the transports only within the member state, but, on the other hand, there is no harmonised tax system. Member states can use different tax rates and this results in the fact that physical transport and the taxation of the products are separated, stimulating VAT fraud.

The method of the VAT fraud is drawn in Figure 2. As it is shown in the Figure only Firm 1, Firm 2 and Firm 3 take part in the fraud, other companies in the food chain are innocent but nevertheless beneficiaries of the fraud as the prices after the multiplied theft of VAT can be a lot more favourable and thus more competitive on the market. (Please note that by the VAT fraud the consumers are beneficiaries, too, as the consumer prices are lower as a result.) Firm 1 exports the products according to the EU rules without VAT. Firm 2, on the other side of the border, imports the products and should pay the VAT according to the tax rates of its own country. But this firm, a 'phantom company' does not pay the tax but sells the products to Firm 3 at a favourable price. Firm 2 after a certain amount of time disappears, usually its owners are foreigners or homeless people without any property. Firm 3, the beneficiary, buys 
the products and sells them according to the rules with invoice, VAT, etc. After this point the transactions are totally legal, but the price is reduced. Sometimes, Firm 3 reexports the products to the original country and the products go around several times and the illegal firms multiply their profit.

Figure 2: Typical method of VAT fraud

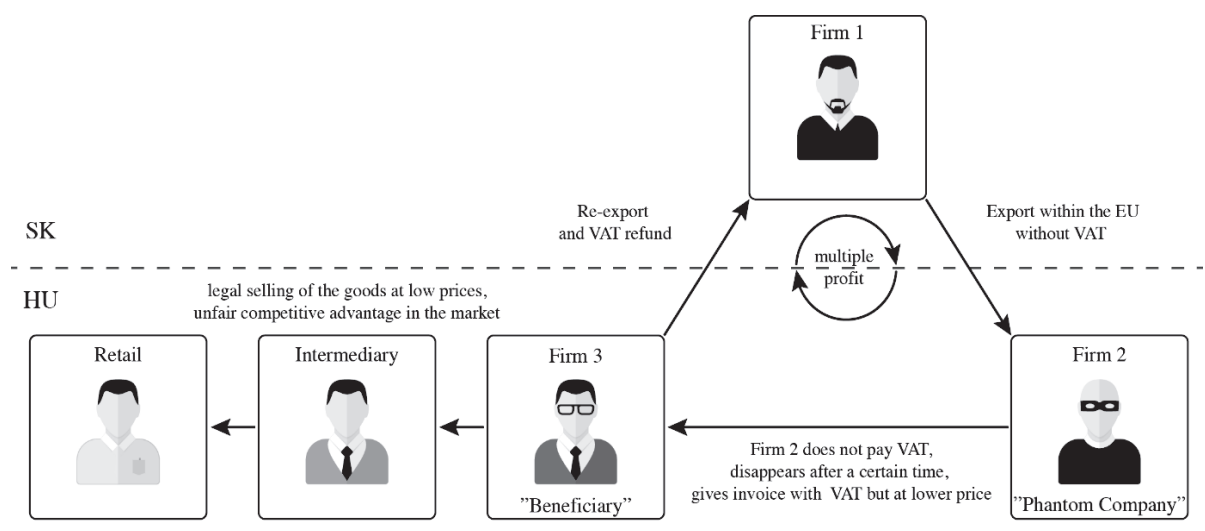

Source: Department of Food Chain Analysis, Research Institute for Agricultural ECONOMICS

The European Commission (2013) published an estimate of the gap in the value added tax (Fig. 3). According to the calculations of the EU Commission, a total of 193 billion Euros - that is $1.5 \%$ of their GDP - was lost in VAT revenue in 26 member states (Cyprus has not been studied.) in 2011 through violation of the tax regulations or insufficient tax collection. In Hungary, 3.7 billion Euros of VAT has not been paid, representing 3.7\% of the GDP. Significantly, in the neighbouring countries of Hungary the VAT gap was only $1.2 \%$ of the GDP in Austria, while it was $7.9 \%$ in Slovakia and $4 \%$ in Romania. An above-average VAT gap was measured in the new member states, but also the difference between northern and southern countries is apparent: in Greece and Italy a higher VAT gap was measured. 
Figure 3: VAT gap as share of GDP in EU countries, 2011

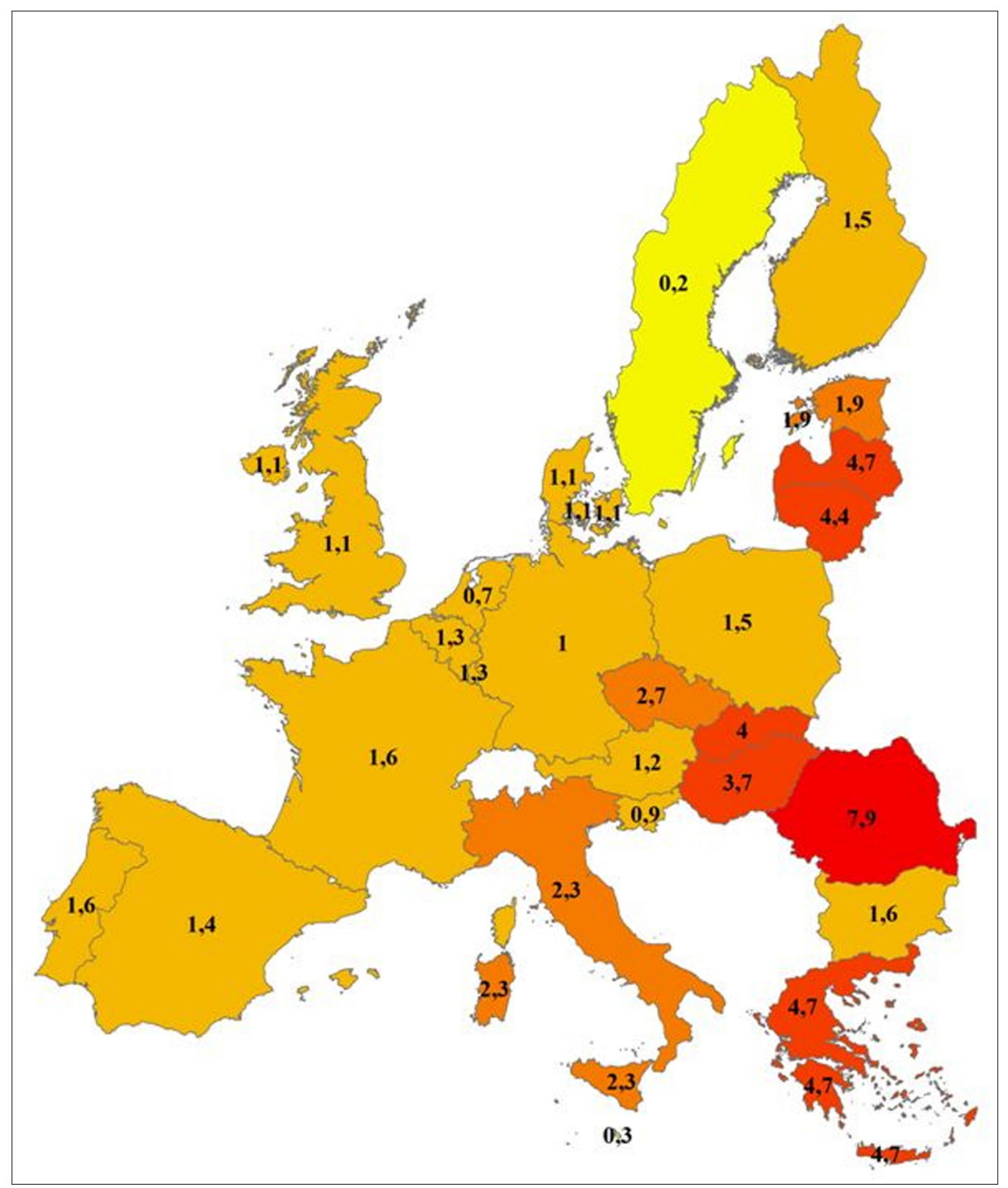

Source: EUROPEAN CoMmission 2013 


\section{Applied methods}

In the analysis of the Research Institute for Agricultural Economics the shadow economy is defined as the totality of all the illegal activities that have been carried out in order to hide all or a part of the income and thus minimising the taxes. This includes illegal production, illegal employment and VAT fraud, too. This approach is important because all of these activities are harmful, regardless of whether they are small crimes or serious fraud cases. Those activities, whose goal is own consumption, have not been included in the term of shadow economy, although they create value.

The share of the shadow economy in the food sector was estimated through indirect and direct methods. Using indirect methods, the comparison of different statistical data was carried out (for example data of the National Statistics Office, Eurostat and other data sources) and the comparison of natural data of animal breeding sectors was prepared.

Using direct methods, we carried out 53 interviews with experts on the food industry, agriculture and the authorities. With the interviews we studied both the size of the shadow economy and the way it operates. Another important direct method were the estimations made by using the data - identified tax deficit - of the National Tax Office.

Special attention was paid to the analysis of foreign trade data. The comparison of the Hungarian agri-food trade data of the National Statistics Office with the 'mirror data' of Eurostat may provide an answer to the question of whether the data of the partner countries are the same and/or the difference is high enough to assume that there is an illegal, non-real export-import flow between the countries. For this purpose, export and import to Hungary were compared to the import and export of the EU member states altogether and one-by-one in order to explore the so-called import and export differences, or the bilateral asymmetry indicators for import and export for the years 2004 to 2012 .

\section{Estimation results}

It was found that the mirror data of the EU member countries were substantially below that of the Hungarian data for Hungarian exports, while the Hungarian data were higher in the Hungarian export. The difference between the mirror data has grown since 2009 and peaked in 2012 (Fig. 4).

The difference has shown variety according to country. The highest difference was experienced in the trade between Hungary and Slovakia (53\% of the total difference) and between Hungary and Romania (10\% of the total difference), while with the other countries the deviation was minimal and could be due to statistical error (Fig. 5). 
Figure 4: Comparison of Hungarian foreign trade statistics with mirror data of trading partners in the EU-27 (2003-2013)

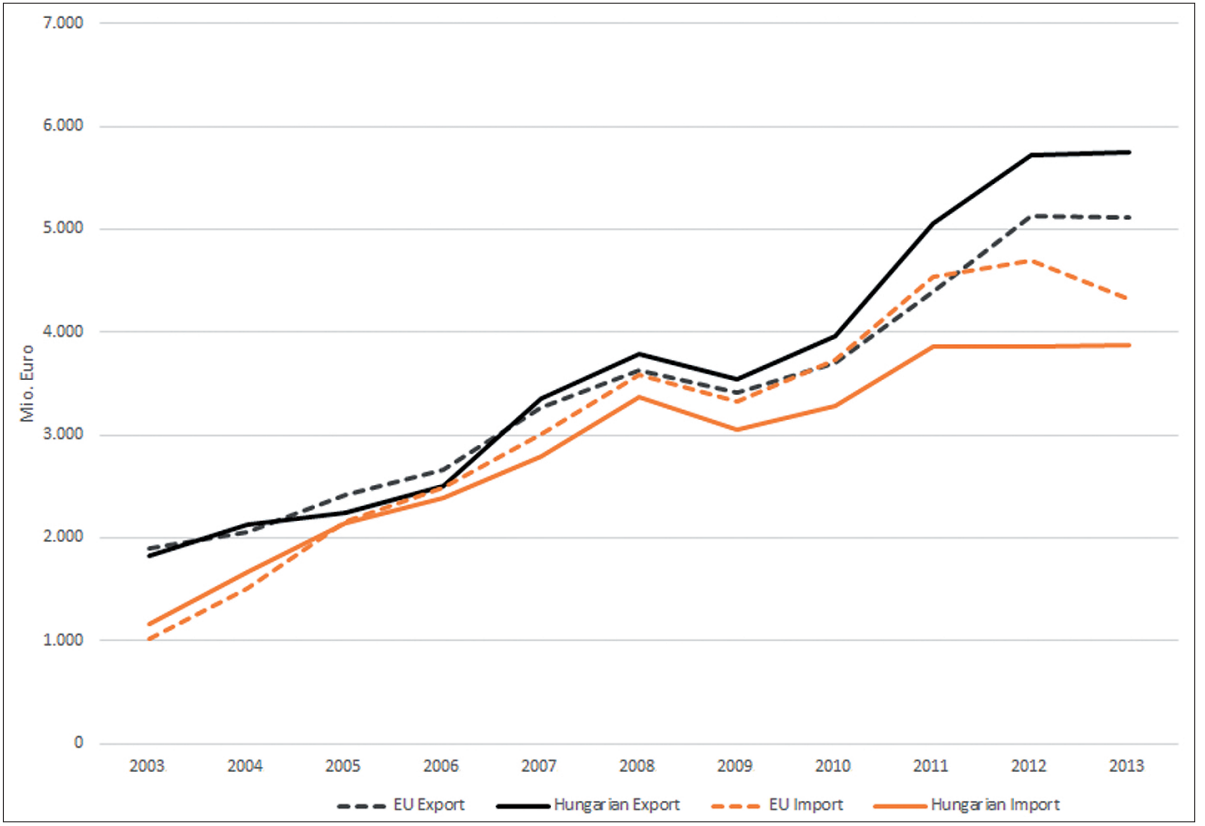

Source: National Statistics Office and Eurostat

Figure 5: Import difference in 2012 by individual EU member states

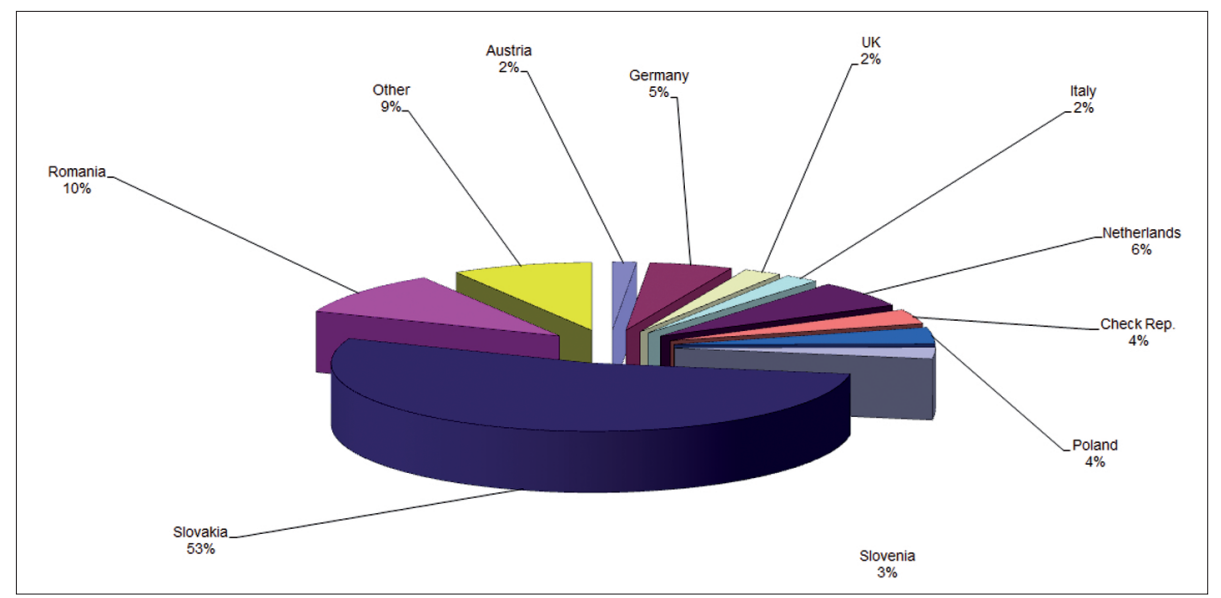

Source: National Statistics Office and Eurostat 
Due to the enormous differences between the mirror data, the trade relations between Hungary and Slovakia were investigated in more detail. This yielded results almost paradoxical, because according to data of the Slovak Statistical Office, Slovakia has performed 1,369 million Euros of food products to Hungary, while according to the Hungarian data, Hungary has only imported commodities at the value of 514 million Euros. The largest difference was seen in the case of sugar (249 million Euros), oilseeds (233 million Euros) and vegetable oil (114 million Euros). These three commodity groups made up altogether almost two-thirds of the import difference. In the case of sugar in particularly, the suspicion of tax fraud was hardened, because according to the DG Agri, the total sugar production of Slovakia amounted only to 163,000 tonnes in 2012. In addition, sugar has durable, transportable property, which can be easily be repackaged and its origin is difficult to prove - these are all characteristics that make it ideal for this type of transaction.

When examining the import differences for the different product groups for the total EU, sugar stands at $11.6 \%$ in the first place, followed by canola seeds $(8.1 \%)$, pork $(6 \%)$ and sunflower oil $(5.9 \%)$.

In export difference, corn was in the first place with $14.4 \%$, followed by sunflower oil $(8.4 \%)$, sunflower seeds $(5.9 \%)$ and rapeseed $(4.2 \%)$.

Since differences between the trade statistics of two countries can be attributed to various reasons, the calculated differences are of course only estimates, but, at this scale, must be considered primarily the result of deliberate fraud. Of course, the fraud in the partner countries could have been accomplished, but since the VAT is highest in Hungary, it seems illogical. To determine the level of VAT fraud carried out by agricultural and food products in 2012, a statistical error of $10 \%$ was assumed in the calculations, i.e. only those relations were considered, where the import and export difference was over this error limit. In the remaining countries in the calculation, the difference was also reduced by $10 \%$. The sum of the estimated VAT gap over the statistical error limits in the Hungarian agricultural foreign trade thus amounted in 2012 to 378 million Euros.

However, this is only part of the VAT gap in the Hungarian state budget. We have to look also for unpaid VAT of the domestic sale of food and agricultural commodities without invoice. This estimate can be based on previous surveys carried out by the National Tax Office, which measured this item to be around 110 million Euros, so altogether the VAT gap of the food economy can be around 488 million Euros in Hungary.

As has already been cited, the European Commission had determined the VAT gap of Hungary to $3.7 \%$ of the GDP in 2011. This would represent a proportionate value of around 242 million Euros, less than half of the amount determined on the basis of the above estimates. 
Another, often criticised element of the Hungarian tax system are the high labour taxes. In Hungary, according to information by the Hungarian Labour Office, the food economy is at second place after the construction industry amongst the sectors most affected by illegal employment. According to the Hungarian Labour Office, in 2012, $5.6 \%$ of the cases have been noticed in food industry. This percentage is significantly higher than the proportion of the sector's GDP (1.9\%), or in total employment $(3.3 \%)$.

The proportion of undeclared work of total employment in the food economy was estimated in our research by comparing the data from the National Tax Office and the data from the National Statistics Office. These two databases were especially suitable for this purpose as the National Tax Office uses institutional statistics (number of employees reported by the companies), while the National Statistics Office (HSO) uses and publishes the employment data based on interviews with a sample of the Hungarian population, asking them if they worked in the last month and not paying attention to the fact if the work was illegal or legal.

According to this comparison it was found that the share of illegal employment was $30-35 \%$ in agriculture and $20 \%$ in the food industry. However, since this deviation may be due to a different handling of data (about 10\%), it seems a real estimation to state that illegal employment in agriculture is approximately $20-25 \%$, and $10 \%$ in the food industry. Based on these figures we can estimate the unpaid taxes and social contribution fees. This gives the following figures on the unpaid payroll taxes and labour costs (Fig. 6).

Overall, the tax gap due to illegal employment is almost 350 million Euros. The failure of state tax revenue in this area therefore lies at approximately the same level as VAT fraud in agricultural trade.

The share of illegal income of the population was estimated by BuBLIK \& То́тн (2013), in 2010 to $18 \%$ of the total income of the Hungarian economy. Here, a relationship between the presence of agricultural activity and the amount of the share of illegal income was proven to be hushed statistically. On this basis, the proportion of illegal income in food economy could be estimated to $25-30 \%$ above the national average.

In order to estimate the overall share of the shadow economy in the food industry, the results of the tax investigations of the National Tax Office of the years 2007-2012 were used. Based on these data, the average tax loss per control was determined, multiplied by the number of registered business entities. Using this method, but remembering that it is noted in literature that this usually overestimates the true proportion of the shadow economy, because controls are focused on risky companies, the results were reduced on the basis of experts' estimates of the theoretical tax loss by 45\%. Thus the tax gap was estimated at 3.3-33.3 billion Euros for the overall economy, which would mean $24.1-34.3 \%$ of the Hungarian GDP. Assuming that the share of 
agriculture in the hidden income is higher than in the economy as a whole, the tax gap of the food economy would be around 2.2-3.2 billion Euros and the share of it in the GDP of the sector is $29.1-49.3 \%$.

Figure 6: Comparison of different databases of HSO and data of the National Tax Office for employment of agriculture and food industry, 2012
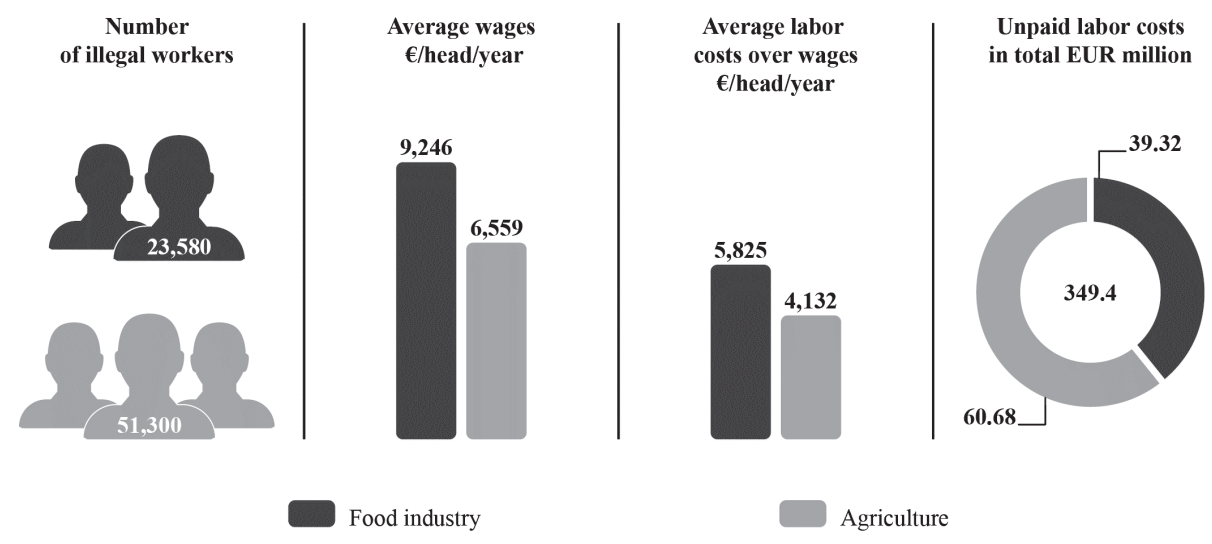

Source: National Statistics Office (HSO) and National Tax Office

\section{Recommendations}

Our suggestions are divided into several sections and discussed in detail at the end of our study.

We examined the possibilities and effects of the reduction of share of cash in the economy, a total reform of the tax and social contribution system and a unified tax system in the EU. These options are largely utopian, though these would provide the best solution against tax fraud.

The application of a reverse VAT system was investigated in detail, as this is a method used in the EU member countries. The reverse VAT system - as stated several times by the Commission - can be only a temporary tool while effective, long-term measures would be designed by the member state. In recent years, the Commission has repeatedly rejected the extensions as well as requests for extensions to other products, so we do not consider it to be a realistic option in the near future for all the sectors except grain and oil seeds. The deadline of the application of the reverse VAT system for cereals and oil seeds were extended to $31^{\text {st }}$ December 2018, but right now Hungary has to start to prepare detailed proposals for long-term solutions in the subsequent period. 
Efficient and promising experience has been seen in other countries by using stricter checks, new administrative rules, closer cooperation between the authorities of the neighbouring countries, exchanging data and information, more intensive use of common actions against the shadow economy. With these tools, VAT and tax fraud can be suppressed to a level that can be tolerated from a budgetary and economic point of view.

In our opinion, the main issue is the general tax moral weakness, which is incorporated into everyday life and practice in Hungary. The consumers themselves are also responsible for this, since it is not their habit to request a receipt for food. The so-called 'grey' employment is widely accepted in society and considered necessary due to the high taxes and social contribution fees.

Therefore, an effective solution can be only achieved in the long term, if the social value judgments slowly would be shaped and distortions in the tax system in Hungary would be eliminated. The interest of the employees should be increased, for example, by creating a more direct link between contributions and the benefits expected. Simultaneously - especially for small-scale production - simple, fixed-income taxes based on the expected incomes could be introduced. These measures, however, are largely beyond the agricultural policy makers' competence. For agriculture, however, we suggest a much more simplified tax system and a reduction in unnecessary discounts.

\section{References}

Brennan G., Buchanen J. (1993), Adózási alkotmány Laviatán számára. In: SemJén A. (ed.), Adózás, adórendszerek, adóreformok. Szociálpolitikai értesítő. Budapest, MTA, Szociológiai Intézet.

Bublik B., Tо́тн I.J. (2013), Rejtett lakossági jövedelmek kistérségi szintű becslése. In: MKK Gazdaság- és Vállalkozáskutató Intézet, 2, p. 36.

Collis J., Jones P. (2003), Közpénzügyek és közösségi döntések. Budapest, Aula.

EURopean Commission (ed.) (2013), Study to quantify and analyse the VAT Gap in the EU-27 Member States. Final Report. TAXUD/2012/DE/316. Brussels.

Fleming M., Roman J., Farrel G. (2000), The Shadow Economy. In: Journal of International Affairs, 53, 2, pp. 387-409.

Központi Statisztikai Hivatal (ed.) < www.ksh.hu >

Krekó J., Kiss P.G. (2008), Adóelkerülés és a magyar adórendszer (= MNB-tanulmányok, 65). Budapest, Magyar Nemzeti Bank.

Merkel K., То́тн K. (2010), A mezőgazdaság adózása különös tekintettel az egyéni gazdaságokra. Budapest, Agrárgazdasági könyvek, Agrárgazdasági Kutató Intézet.

Meyer D. (2006), Ist die Transformation planbar? In: Dix H., Schroen M., Wenzel H.-D. (eds.), Bosnien und Herzegowina und die Soziale Marktwirtschaft im 21. Jahrhundert (= Public Economics Series), pp. 63-76. Bamberg, BERG Verlag. 
NAGY G. (2010), Adózás és költségvetési fizetési kötelezettségek ellenőrzésének módszertana és informatikai támogatottsága. PhD. thesis, Miskolci Egyetem, GTK, Vállalkozáselmélet és gyakorlat Doktori iskola.

Nemzeti Adóés VÁmhivatal (NAV) (ed.) (2011-2012), NAV Évkönyv. Budapest.

SchneIder F., Enste D.H. (2003), The Shadow Economy. An International Survey. Cambridge, Cambridge University Press.

SchneIder F. (2010), The Shadow Economy in Europe, 2011. Linz, Johannes-KeplerUniversität.

Schneider F., Buehn A., Montenegro C.E. (2010), Shadow Economies all over the World: New Estimates for 162 Countries from 1999 to 2007. In: International Economic Journal, 24, 4, pp. 443-461.

Schneider F., Buehn A. (2013), Shadow Economy in Highly Developed OECD Countries: What are the driving forces? (= IZA Discussion Paper). Bonn, Institute for the Study of Labour, University of Bonn. 